(Київський національний університет культури і мистецтв)

\title{
ПІДГОТОВКА МАЙБУТНІХ УЧИТЕЛІВ ІНОЗЕМНИХ МОВ ДО ЗАСТОСУВАННЯ ТЕХНОЛОГІЇ ПОДКАСТИНГУ У ПРОФЕСІЙНІЙ ДІЯЛЬНОСТІ
}

У статті розглянуто особливості підготовки майбутніх учителів до застосування технології подкастингу у професійній діяльності вчителів іноземних мов. Наведено приклади та різновиди подкастів, онлайн ресурсів та сучасних технологій вивчення іноземних мов, иляхи їх використання, а також розглянуто алгоритм роботи з подкастами та скриптами. Проаналізовано практичний аспект використання подкастів у прочесі вивчення іноземних мов, зокрема створення власних записів з метою удосконалення навичок іншомовного мовлення та розвитку в студентів креативності.

Ключові слова: професійна діяльність, технологія, подкастинг, підготовка майбутніх вчителів, діяльнісно-орієнтований підхід.

Вступ. Підготовка майбутніх учителів іноземних мов передбачає готовність застосовувати новітні технології у професійній діяльності, що в умовах сучасної глобалізації є невід'ємною частиною процесу формування комунікативної іншомовної компетентності. Сьогодення диктує педагогам обирати найефективніші технології викладання іноземних мов: використання аудіо-візуальних матеріалів, інтернетресурсів, освітніх платформ, мультимедійних засобів навчання та особистих гаджетів студентів. Однією 3 провідних технологій навчання є технологія подкастингу - публікування аудіо або відео матеріалів у мережі Інтернет та завантаження їх на пристрої для прослуховування у будь-який зручний час [1].

Аналіз основних досліджень і публікацій із зазначеної проблеми. Темі подкастингу у професійній діяльності майбутніх учителів іноземних мов присвячено роботи таких українських педагогів та вчених, як С. С. Данилюк, Н. В. Грицик, І. М. Дробіт, О. С. Бецько, Т. В. Шиян, Н. В. Кардашова. Незважаючи на кількість написаних наукових праць щодо ефективності подкастів та широке застосування автентичних матеріалів за кордоном, до технології подкастингу звертаються порівняно не часто, що пояснюється недостатньою підготовкою висококваліфікованих фахівців 3 мови та неготовністю вчителів застосовувати сучасні поширені в європейських країнах методики та технології.

Формулювання мети і завдань статті. Метою статті $є$ розглянути практичний аспект застосування технології подкастингу у професійній діяльності майбутніх вчителів іноземних мов та створення власних подкастів з метою удосконалення у студентів навичок іншомовної комунікативної компетентності. Відповідно до поставленої мети нами сформовано такі завдання:

- визначити сутність та проаналізувати переваги технології подкастингу у професійній діяльності вчителя іноземних мов;

- $\quad$ розробити алгоритм та модель роботи з автентичними матеріалами, іншомовними подкастами та їх скриптами;

- обгрунтувати ефективність створення власних подкастів на заняттях з іноземної мови.

Важливим аспектом у підготовці майбутніх вчителів іноземних мов $є$ імплементація у навчальний процес сучасних педагогічних та інформаційних технологій, обізнаність педагога в різних галузях та провідних тенденціях розвитку міжнародної системи освіти, адже як зазначає Ю. А. Рибінська, "динамізм сучасної освіти, швидкі зміни в галузях людської діяльності спричинили зростання ролі фахівця з високим творчим потенціалом, готового до постійного вдосконалення своєї професійної підготовки" [2: 87].

Використання подкастів з навчальною метою - поширена практика в багатьох країнах світу, подкаст це цифровий медіа-файл, що розповсюджується в мережі і за змістом нагадує радіошоу, звукову виставу, містить інтерв'ю, лекції чи випуск новин, що належить до усного жанру мовлення [1]. Аналіз попередніх досліджень дозволяє визначити такі переваги застосування технології подкастингу, як автентичність, актуальність, компетентність, автономність, багатоканальне сприйняття, мобільність, багатофункціональність, продуктивність, інтерактивність (Кардашова Н. В.); стимулювання самостійної роботи студентів у позааудиторний час, сприяння міжкультурної взаємодії у мережі Інтернет, занурення у реальне спілкування носіїв мови, знайомство з їх індивідуальними особливостями від тембру голосу до акценту, підвищення мотивації до оволодіння іноземною мовою (Грицик Н. В.); поява вибору у відборі цікавого фонетичного матеріалу, формування навичок аудіювання та здатності сприймати різні стилі мовлення з різними акцентами й інтонаціями, вдосконаленню навичок говоріння, котре стимулює обговорення тем, розширюючи тим самим кругозір сучасних фахівців (Данилюк С. С.).

На основі класифікації, розробленої Дж. Стенлі, який виділяє автентичні та методичні подкасти, а також подкасти, створені вчителями або студентами, розглянемо кожний їх вид та специфіку використання [3]. 
Практичний аспект підготовки майбутніх вчителів до застосування даної технології у професійній діяльності полягає у використанні автентичних подкастів з метою удосконалення професійних навичок іншомовного мовлення, а також методичних подкастів, що слугуватимуть додатковим методичним джерелом знань для майбутніх вчителів іноземних мов. Для роботи з подкастами американський вчений Ентоні Шмідт пропонує свою методику використання Listening Journals, ведення журналів певних записів 3 метою навчання студентів навичок аудіювання. Е. Шмідт акцентує увагу на формуванні у студентів навичок "слухання" та стверджує, що "більшість аудіювань проводяться 3 метою ознайомлення 3 новою граматикою чи темою заняття, для тестування розуміння (але не навчання як зрозуміти) або ж для розпізнання різних акцентів", тому виникає потреба навчити студентів як слухати, надавши їм більш інтенсивні та екстенсивні інструкції з аудіювання [4]. Вирішенням даної проблеми, на думку вченого, $є$ використання наступних журналів прослуховувань аудіо-матеріалів.

\section{General Listening Journal Template}

\begin{tabular}{|l|l|l|}
\hline Website & Audio Name & Level / Other Information \\
\hline & & \\
\hline
\end{tabular}

Summary: What was the listening about?

\begin{tabular}{|l|}
\hline \\
\\
\hline 1. \\
2. \\
3. \\
4. \\
5. \\
6.
\end{tabular}

Vocabulary: What words did you learn?

Activities: What did you do? What scores did you get?

\begin{tabular}{|c|c|c|c|}
\hline \multicolumn{4}{|l|}{ Self-Assessment } \\
\hline Question & Yes & No & Maybe \\
\hline \multicolumn{4}{|l|}{ The speed was OK. } \\
\hline \multicolumn{4}{|l|}{ The Vocabulary was OK. } \\
\hline \multicolumn{4}{|l|}{ The Pronunciation was OK. } \\
\hline \multicolumn{4}{|l|}{ This helped my listening skills. } \\
\hline \multicolumn{4}{|l|}{ I think my listening skills are improving. } \\
\hline $\begin{array}{l}\text { I need to improve (please circle all that } \\
\text { numbers / listening to fast speech / listening } \\
\text { accents / my vocabulary / my pronunciation }\end{array}$ & $\begin{array}{l}\text { / liste } \\
\text { for a } 1\end{array}$ & $\begin{array}{l}\text { detai } \\
\text { e / li }\end{array}$ & $\begin{array}{l}\text { tening to } \\
\text { to other }\end{array}$ \\
\hline
\end{tabular}

Робота 3 автентичними подкастами відкриває для вчителя іноземних мов величезний спектр можливостей використання різноманітних ресурсів та технологій. 3 метою подолання фонетичних, лексичних та граматичних труднощів при прослуховуванні автентичних подкастів (складна побудова речень, рідкісні граматичні конструкції, часом нечітка вимова спікера) вважаємо доцільним використання скриптів, тобто тексту подкасту. Працюючи зі скриптами, майбутні вчителі іноземних мов мають оперувати знаннями про допоміжні інтернет-ресурси, застосування яких має на меті оптимізувати процес вивчення іноземних мов та залучити студентів до самостійної позааудиторної роботи. Одним 3 таких pecypсів $є$ cloze test creator на сайті http://l.georges.online.fr/tools/cloze.html, за допомогою якого студент має можливість самостійно створити інтерактивне завдання 3 заповнення пропусків відповідно до тих лексичних одиниць, які він обиратиме. Таким чином, прослуховуючи подкаст, студент зосереджуватиме увагу на тих лексичних одиницях та граматичних структурах, які $є$ найважчими для сприйняття i диференціюватиме їх із загального мовного потоку.

Ефективним інструментом для перевірки засвоєних студентами знань $\epsilon$ он-лайн ресурс http://create.kahoot.it. Це інтерактивна освітня платформа, що дозволяє вчителям створювати опитування, вікторини, ігри, тести, дискусії тощо і застосовувати їх на заняттях, використовуючи свій гаджет та ангажуючи інших студентів працювати на власних мобільних телефонах або інших пристроях, що мають доступ до Інтернету. Перевагами даної платформи є можливість здійснювати миттєвий контроль знань 
студентів, які вчитель отримує в електронному вигляді на свій пристрій; мотивація студентів за рахунок використання альтернативних методів оцінювання на противагу традиційному написанню тесту, що часто демотивує студентів для подальшої роботи; можливість створювати власні завдання, вікторини, опитування іноземною мовою для перевірки знань інших студентів та водночас тренування власних іншомовних комунікативних вмінь та навичок; створення позитивної атмосфери завдяки інтерактивному характеру та ігровому компоненту даного ресурсу.

На сучасному етапі розвитку науки та освіти підготовка майбутніх вчителів іноземних мов означає формування висококваліфікованих фахівців, які здатні екстраполювати власні навички та знання у професійній діяльності. У контексті даного дослідження вважаємо за потрібне впроваджувати технологію подкастингу в процесі вивчення іноземної мови, а саме залучати студентів до практики створення власних подкастів.

Як зазначає С. С. Данилюк, "технологія роботи 3 подкастом збігається 3 технологією роботи над аудіотекстом і має чітку послідовність у діях викладача та майбутніх фахівців", в той час як питання створення власних подкастів у процесі вивчення іноземної мови залишається нерозв’язаним [5: 26].

Зарубіжна практика показує, що створення подкастів в процесі підготовки майбутніх вчителів іноземної мови має сильне теоретичне та практичне підгрунтя, адже реалізація таких завдань, як створення власних подкастів стимулює розвиток креативності у студентів, прагнення до нових пошуків та знань. М. Свейн та С. Лепкін, відомі американські педагоги, запропонували свій підхід, що полягає у записі студентами власного висловлювання 3 його подальшим прослуховуванням та редагуванням. Таким чином, повторно прослуховуючи та редагуючи власний запис, студенти мають зворотній зв'язок (feedback) з вчителем та іншими студентами, який, на думку американських вчених, виступає конструктивним чинником у формуванні іншомовної комунікативної компетентності [6]. 3 технічної точки зору, реалізація даного підходу можлива за наявності у студентів засобів запису: диктофону чи особистих гаджетів і не потребує особливих технічних навичок.

У педагогічному дослідженні "Podcasting en anglais, partage et création" французький педагог МаріЕленФаскель звертається до діяльнісно-орієнтованого підходу. Відповідно до положень Загальноєвропейських Рекомендацій з мовної освіти суть даного підходу полягає у тому, що "користувачі мови й ті, що ії вивчають, є насамперед "соціальними агентами", або ж членами суспільства. Вони мають виконувати певні завдання (що необов'язково пов'язані з мовленням) у певних умовах, специфічному оточенні та в окремій сфері діяльності" [7]. М. Е. Фаскель стверджує, що реалізація таких діяльнісноорієнтованих завдань, як створення подкастів, дозволяє студенту самостійно усвідомити свої можливості та оцінити власний потенціал. Крім того, створюючи та публікуючи подкасти в мережі Інтернет, студенти долучаються до корпоративної роботи, адже мають змогу працювати в команді, самостійно обираючи собі напарника. Дослідниця наголошує на проблемах відсутності мотивації у студентів, подолання мовного бар'єру, невпевненості у собі, страху висловлюватись іноземною мовою письмово чи усно, які безумовно виступають деструктивними чинниками у вивченні іноземної мови, проте можуть бути усунені шляхом впровадження технології подкастингу, що корелює з основними засадами дільнісно-орієнтованого підходу до навчання [8].

Зважаючи на ряд переваг даної технології, потрібно зазначити, що створення подкастів на заняттях вимагає від учителів іноземних мов високого рівня володіння іноземною мовою та професіоналізму, зокрема при підготовці майбутніх вчителів іноземних мов слід врахувати відсутність наявних методичних рекомендацій щодо створення подкастів в класі у загальноосвітній програмі навчання в Україні.

До прикладу програма вивчення англійської мови у міжнародних школах багатьох європейських країн включає цілий розділ навчання, що присвячений використанню подкастингу на заняттях з іноземної мови. Алгоритм організації навчання у роботі з подкастами надається вчителям іноземних мов у методичних рекомендаціях, що базується на національній навчальній програмі Великобританії із зазначеною кількістю годин, встановленими завданнями та цілями, описом аудиторної та позааудиторної роботи. Рекомендований шлях навчання учнів подкастингу може варіюватись відповідно до освітніх цілей та завдань, які ставить перед собою вчитель, проте схема та плани уроків, відображені нижче у таблиці, демонструють загальний алгоритм роботи з подкастами.

Алгоритм роботи зі створення власного подкасту

\begin{tabular}{|l|l|l|l|}
\hline Lesson & Main focus and objectives & Teaching summary & Activity description \\
\hline $\begin{array}{l}\text { Comprehension } \\
\mathbf{1}\end{array}$ & $\begin{array}{l}\text { Listen and respond to an } \\
\text { audio story } \\
\text { Develop positive attitude to } \\
\text { reading and understanding of } \\
\text { what the students read: Listen } \\
\text { and discuss wide range of } \\
\text { text types; }\end{array}$ & $\begin{array}{l}\text { Present the topic of the podcast } \\
\text { and introduce the concept of } \\
\text { audio stories. Have you ever } \\
\text { listened to a podcast, radio story } \\
\text { or audio book? }\end{array}$ & $\begin{array}{l}\text { After listening retell the } \\
\text { events in sequence and } \\
\text { discuss the story's effect. } \\
\text { What images does it } \\
\text { bring to your mind? } \\
\text { Listen and indicate } \\
\text { where the sounds } \\
\text { appear. }\end{array}$ \\
\hline
\end{tabular}




\begin{tabular}{|c|c|c|c|}
\hline $\begin{array}{l}\text { Comprehension } \\
2\end{array}$ & $\begin{array}{l}\text { Listen and respond to an } \\
\text { audio story } \\
\text { Explore characters in detail. } \\
\text { Participate actively in } \\
\text { conversations; speculate, } \\
\text { hypothesise, imagine and } \\
\text { explore ideas. }\end{array}$ & $\begin{array}{l}\text { Listen to the second part of the } \\
\text { podcast, discuss and analyze the } \\
\text { characters of the story. } \\
\text { What are they like? }\end{array}$ & $\begin{array}{l}\text { The students complete } \\
\text { the chart about the } \\
\text { characters and get ready } \\
\text { to describe them. }\end{array}$ \\
\hline $\begin{array}{l}\text { Comprehension } \\
3\end{array}$ & $\begin{array}{l}\text { Listen and respond to an } \\
\text { audio story } \\
\text { Read a story aloud } \\
\text { Articulate and justify } \\
\text { answers; } \\
\text { Gain the interest of the } \\
\text { listener; } \\
\text { Select and use appropriate } \\
\text { registers. }\end{array}$ & $\begin{array}{l}\text { Listen to the last part of the } \\
\text { podcast. Discuss the ending. } \\
\text { Listen to the first few minutes of } \\
\text { the episode. When does the } \\
\text { narrator speak loudly, quietly, } \\
\text { quickly or slowly? What kind of } \\
\text { voices are used in different } \\
\text { characters? } \\
\text { Ask the students to find powerful } \\
\text { words and phrases in the story. }\end{array}$ & $\begin{array}{l}\text { Practice reading the } \\
\text { story aloud in groups. } \\
\text { Each student in a group } \\
\text { reads a different part of } \\
\text { the story. The other } \\
\text { students use "Two Stars } \\
\text { and a Wish" to suggest } \\
\text { improvements (reading } \\
\text { louder, softer, in } \\
\text { different voices etc). }\end{array}$ \\
\hline $\begin{array}{l}\text { Depth focus 1: } \\
\text { Descriptive } \\
\text { language }\end{array}$ & $\begin{array}{l}\text { Explore synonyms, powerful } \\
\text { vocabulary, settings and } \\
\text { mood. } \\
\text { Identify how language, } \\
\text { structure and presentation } \\
\text { contribute to the meaning. }\end{array}$ & $\begin{array}{l}\text { The students discuss unfamiliar } \\
\text { words, suggests synonyms and } \\
\text { find the ways the author has } \\
\text { described emotions(fear, joy, } \\
\text { surprise) and sound(circle in } \\
\text { different colours). } \\
\text { Can you think of other words and } \\
\text { phrases we could use? }\end{array}$ & $\begin{array}{l}\text { The students complete } \\
\text { 'mood tracker' to explore } \\
\text { how mood and thoughts } \\
\text { of the characters change } \\
\text { at different points in the } \\
\text { story. }\end{array}$ \\
\hline $\begin{array}{l}\text { Long } \\
\text { composition } 1\end{array}$ & $\begin{array}{l}\text { Shared learning and teacher } \\
\text { modelling of a class story } \\
\text { podcast. } \\
\text { Plan their writing: discuss } \\
\text { writing similar to that which } \\
\text { they are planning to write; } \\
\text { discuss and record ideas; } \\
\text { draft and write: Oral } \\
\text { rehearsal, use of rich } \\
\text { vocabulary, and increasing } \\
\text { range of sentence structures; } \\
\text { organize paragraphs around a } \\
\text { theme in narratives. }\end{array}$ & $\begin{array}{l}\text { Explain that the students are } \\
\text { going to write a three episode } \\
\text { podcast. Discuss what they } \\
\text { learned about podcasts. } \\
\text { Suggest a starting point, } \\
\text { brainstorm what might happen, } \\
\text { record ideas. } \\
\text { Ask the students where powerful } \\
\text { words might be used. }\end{array}$ & $\begin{array}{l}\text { Suggest where sound } \\
\text { effects might be used } \\
\text { during the modelled first } \\
\text { episode. }\end{array}$ \\
\hline $\begin{array}{l}\text { Long } \\
\text { Composition } 2\end{array}$ & $\begin{array}{l}\text { Write first draft of a story } \\
\text { podcast. } \\
\text { Draft and write: Oral } \\
\text { rehearsal, use of rich } \\
\text { vocabulary, and increasing } \\
\text { range of sentence structures; } \\
\text { Organise paragraphs around a } \\
\text { theme. Create settings, } \\
\text { character and plot. }\end{array}$ & $\begin{array}{l}\text { The students share their plans } \\
\text { from previous session and use } \\
\text { Two Stars and a Wish to make } \\
\text { suggestions for improvements. }\end{array}$ & $\begin{array}{l}\text { The students rehearse } \\
\text { sentences orally, write } \\
\text { the first draft of their } \\
\text { story }\end{array}$ \\
\hline $\begin{array}{l}\text { Long } \\
\text { Composition } 3\end{array}$ & $\begin{array}{l}\text { Review and edit to produce a } \\
\text { final draft of a story podcast. } \\
\text { Evaluate and edit: Assess } \\
\text { own and other's writing. }\end{array}$ & $\begin{array}{l}\text { Explain that in this session the } \\
\text { students will review the writing } \\
\text { done in the previous session, } \\
\text { making suggestions for changes } \\
\text { and writing a final draft. } \\
\text { Play the podcast, ask the students } \\
\text { to listen to the sound effects and } \\
\text { the narrator's voice. } \\
\text { Discuss adding sound effects to } \\
\text { the stories. What could you bring } \\
\text { to the next session to make } \\
\text { sounds with? }\end{array}$ & $\begin{array}{l}\text { The students write a } \\
\text { final draft of their } \\
\text { podcast. }\end{array}$ \\
\hline Presentation 1 & Practice reading stories aloud & Explain that in this session the & In their groups, the \\
\hline
\end{tabular}




\begin{tabular}{|c|c|c|c|}
\hline & & $\begin{array}{l}\text { students will decide where to add } \\
\text { sound effects to their stories and } \\
\text { practice performing their } \\
\text { podcasts. } \\
\text { Remind the students that that } \\
\text { when they read aloud they should } \\
\text { think about speed, volume and } \\
\text { tone of voice. } \\
\text { How might each character } \\
\text { speak? }\end{array}$ & $\begin{array}{l}\text { children decide where to } \\
\text { add sound effects and } \\
\text { how to make the noises. } \\
\text { After that, they practice } \\
\text { performing their stories. }\end{array}$ \\
\hline Presentation 2 & $\begin{array}{l}\text { Perform and record story } \\
\text { podcast. }\end{array}$ & $\begin{array}{l}\text { Record the student's podcasts, } \\
\text { including their sound effects. } \\
\text { Post the files on-line, on your } \\
\text { school/university site, blog or } \\
\text { social network. } \\
\text { Alternatively, provide time } \\
\text { during assembly or invite other } \\
\text { people to perform the podcasts in } \\
\text { front of a real audience. }\end{array}$ & $\mathrm{N} / \mathrm{A}$ \\
\hline
\end{tabular}

Характерною рисою даної роботи виступає повна свобода дій вчителя, який в процесі навчання впроваджує рекомендовані британською програмою заняття з граматики, які можуть бути необхідними учням у процесі написання власних текстів, а пізніше запису індивідуальних або групових подкастів [9].

Висновки. Таким чином, залишаються актуальними питання подальшої праці та розробки нових шляхів роботи з сучасними інноваційними технологіями та їх реалізації у професійній діяльності вчителів іноземних мов.

У процесі дослідження особливостей та пошуку шляхів використання технології подкастингу приходимо до висновку, що найефективнішим засобом вивчення іноземної мови $\epsilon$ не лише прослуховування записів та подальша робота з його змістом, а написання власних текстів та запис особистих або групових подкастів. Вважаємо, що такий вид освітньої діяльності повинен бути інтегрований майбутніми вчителями іноземних мов у загальну систему освіти України, адже окрім усіх вище зазначених переваг використання подкастів, продукування власних висловлювань іноземною мовою обумовлює креативний розвиток мислення студентів, удосконалює навички іншомовної комунікативної компетентності та сприяє створенню позитивного клімату на заняттях з іноземної мови. Перспективи подальших досліджень вбачаємо у подальшому вивченні шляхів впровадження інноваційних методів вивчення іноземних мов та популяризації технології подкастингу в професійній діяльності майбутніх вчителів іноземних мов.

\section{СПИСОК ВИКОРИСТАНИХ ДЖЕРЕЛ ТА ЛІТЕРАТУРИ}

1. Stanley G. Podcastingfor ELT/ G. Stanley // Teachingenglish.org [Electronic resource]. - 2005. URL : $\mathrm{http} / / / w w w . t e a c h i n g e n g l i s h . o r g . u k / t h i n k / a r t i c l e s /$ podcasting-elt. - Дата звернення 28.03.2012.

2. Fasquel M.-H. Création et podcasting en classe de langue : la collaboration au service de la communication compte rendu d'un projet en classe d'anglais / M.-H. Fasquel. - Artois Presses Université, 2015.

3. Wordsmith Unit Plan 4.1. // Sounds Spooky. - Pearson Education, 2013. - Retrieved from https://www.activelearnprimary.co.uk.

4. Рибінська Ю. А. Підвищення рівня володіння англійською мовою майбутніми філологами як умова інтеграції у міжнародний освітній простір / Ю. А. Рибінська // "Youngscientist". - № 4.1 (31.1), 2016. - С. 87-90.

5. Данилюк С.С. Подкаст як засіб формування професійної компетентності сучасних фахівців// Педагогіка формування творчої особистості у вищій і загальноосвітній школах: [зб. наук. пр.]. - Вип. № 34 (87). - Класич. приват. ун-т ; [голова ред. ради : Монаєнко А. О. ; голов. ред. : Сущенко Т. І. ; чл. редкол. : В. Й. Бочелюк та ін.]. - Запоріжжя : Класич. приват. ун-т, 2014. - С. 153-160.

6. Schmidt A. Listening Journals for Extensive and Intensive Listening Practice / A. Schmidt // English Teaching Forum. - Volume 54. - Number 2, 2016. - P. 2-11.

7. Lara Ducate and Lara Lomicka Podcasting: an Effective Tool for Honing Language Students' Pronunciation // Language Learning \& Technology. - Volume 13. - Number 3, 2009. - P. 66-86.

8. Кардашова Н. В. Англомовний подкаст як засіб формування компетентності в аудіюванні студентів мовних спеціальностей / Н. В. Кардашова // Вісник КНЛУ. - Серія Педагогіка та психологія. - Випуск 24, 2015. C. $176-185$.

9. Загальноєвропейські Рекомендації з мовної освіти : вивчення, викладання, оцінювання/ Науковий редактор українського видання доктор пед. наук, проф. С. Ю. Ніколаєва. - К. : Ленвіт, 2003. - 273 с. 


\section{REFERENCES (TRANSLATED \& TRANSLITERATED)}

1. Stanley G. Podcastingfor ELT/ G. Stanley // Teachingenglish.org [Electronic resource]. - 2005. URL : http://www.teachingenglish.org.uk/think/articles/podcasting-elt. - Accessed date 28.03.2012.

2. Fasquel M.-H. Création et podcasting en classe de langue : la collaboration au service de la communication compte rendu d'un projet en classe d'anglais / M.-H. Fasquel. - Artois Presses Université, 2015.

3. Wordsmith Unit Plan 4.1. // Sounds Spooky. - Pearson Education, 2013. - Retrieved from https://www.activelearnprimary.co.uk.

4. Rybinska Yu. A. Pidvyschennia rivnia volodinnia angliis'koyu movoiu maibutnimy filologamy yak umova integratsii u mizhnarodnyi osvitnii prostir [Upgrading of Prospective Teachers' English Language Skills as a Condition for Integration into the International Educational System] / Yu. A. Rybinska // "Youngscientist". - № 4.1 (31.1), 2016. S. 87-90.

5. Danyliuk S. S. Podkast yak zasib formuvannia profesiinoi kompetentnosti suchasnykh fakhivtsiv [Podcast as a Means of Modern Educators' Professional Competence]// Pedagogika formuvannia tvorchoi osobystosti u vyschii i zagal'noosvitnii shkolakh [Pedagogy of Creative Personality Formation in High and Comprehensive School] : [zb. nauk. pr.]. - Vyp. № 34 (87). - Klasych. pryvat. un-t ; [golova red. rady : Monaienko A. O. ; golov. red. : Sucshenko T. I. ; chl. redkol. : B. Y. Bocheliuk ta in.]. - Zaporizhzhia : Klasuch. pryvat. un-t, 2014. - S. 153-160.

6. Schmidt A. Listening Journals for Extensive and Intensive Listening Practice / A. Schmidt // English Teaching Forum. - Volume 54. - Number 2, 2016. - P. 2-11.

7. Lara Ducate and Lara Lomicka Podcasting: an Effective Tool for Honing Language Students' Pronunciation // Language Learning \& Technology. - Volume 13. - Number 3, 2009. - P. 66-86.

8. Kardashova N. V. Anglomovnyi podkast yak zasib formuvannia kompetentnosti v audiyuvanni studentiv movnykh spetsial'nostei [English Podcast as a Means of Competence Formation through Students of Linguistic Specialties' Listening] / N. V. Kardashova // Visnyk KNLU [Kyiv National Linguistic University Journal]. - Seriia Pedagogika ta Psychologiia. - Vypusk 24, 2015. - S. 176-185.

9. Zagal'noievropeis'ki Rekomendatsii z movnoi osvity: vyvchennia, vykladannia, otsiniuvannia [Common European Framework of Reference for Languages] / Naukovyi redaktor ukrains'kogo vudannia doktor ped. nauk, prof. S. Yu. Nikolaieva. - K. : Lenvit, 2003. - 273 s.

\section{Климчук А. М. Подготовка будущих учителей к применению технологии подкастинга в профессиональной деятельности.}

В статье рассмотрены особенности подготовки будущих учителей к применению технологии подкастинга в профессиональной деятельности учителей иностранных языков. Приведены примеры и разновидности подкастов, пути их использования, а также рассмотрен алгоритм работы с подкастами и скриптами. Проанализированы практический аспект использования подкастов в прочессе изучения иностранного языка, в частности создание собственных записей с иелью усовершенствования навыков иноязычной речи и креативного развития студентов.

Ключевые слова: профессиональная деятельность, технология, подкастинг, подготовка будущих учителей, деятельностно-ориентированный подход.

\section{Klymchuk A. M. Podcast Technology in Preparation of the Future Foreign Language Teacher's Professional Activity.}

The article deals with the peculiarities of podcast technology and its usage in preparation of the future foreign language teacher's professional activity. The practical aspects and the usage of podcasts in foreign language teaching have been analyzed and the efficiency of creating personal or group podcast has been proved. Apart from that, the numbers of online resources and variety of podcast activities have been illustrated with examples and methodological instructions of its practical usage. The following article proceeds us with the topic of podcasts creation by students as the current research is aimed to prove the efficacy of using podcasts in the classroom, to highlight the catholicity of communicative competence formation and envisage the assets of establishing podcasts as an integrated part of the national curriculum. The content of podcast technology, its advantages and correlation with activity-oriented approach were investigated and analyzed. In the course of this article contemporary teaching techniques and methods were suggested to put into practice of foreign language teaching in order to optimize and differentiate the educational process and to achieve high results.

Key words: professional activity, technology, podcasting, preparation of future foreign language teachers, activityoriented approach. 